\title{
Variation in bleaching sensitivity of two coral species across a latitudinal gradient on the Great Barrier Reef: the role of zooxanthellae
}

\author{
Karin E. Ulstrup ${ }^{1,2}$, Ray Berkelmans ${ }^{1}$, Peter J. Ralph ${ }^{2}$, Madeleine J. H. van Oppen ${ }^{1, *}$ \\ ${ }^{1}$ Australian Institute of Marine Science, PMB No. 3, Townsville MC, Queensland 4810, Australia \\ ${ }^{2}$ Institute for Water and Environmental Resource Management, Department of Environmental Science, \\ University of Technology, Sydney, Westbourne St., Gore Hill, New South Wales 2065, Australia
}

\begin{abstract}
The ability of corals to cope with environmental change, such as increased temperature, relies on the physiological mechanisms of acclimatisation and long-term genetic adaptation. We experimentally examined the bleaching sensitivity exhibited by 2 species of coral, Pocillopora damicornis and Turbinaria reniformis, at 3 locations across a latitudinal gradient of almost 6 degrees on the Great Barrier Reef (GBR). Target bleaching temperature was reached by using a ramping rate of $0.2^{\circ} \mathrm{C} / \mathrm{h}$. We found that the bleaching sensitivity and recovery of both species differed between corals with clade D symbionts and those with clade C. However, in P. damicornis bleaching susceptibility corresponded more strongly with latitude than with zooxanthella type and hence, temperature history, suggesting that local adaptation has occurred. The observed bleaching sensitivity was shown by a decrease in photochemical efficiency $\left(F_{\mathrm{v}} / F_{\mathrm{m}}\right)$ in both species of coral. The rate of recovery in $T$. reniformis was highest in explants containing clade D symbionts. The occurrence of clade D in the northern section of the GBR may reflect a long-term response to high sea water temperatures, while the presence of clade D in low abundance in T. reniformis at Heralds Prong Reef and Percy Island may be a result of recent bleaching events.
\end{abstract}

KEY WORDS: Temperature tolerance $\cdot$ Corals $\cdot$ Bleaching $\cdot$ Zooxanthellae $\cdot$ Symbiodinium $\cdot F_{\mathrm{v}} / F_{\mathrm{m}}$

\section{INTRODUCTION}

The symbiotic association between coral hosts and their algal endosymbionts, commonly known as zooxanthellae, is sensitive to increasing seawater temperatures combined with high irradiances (Muscatine 1990, Glynn 1996, Berkelmans \& Oliver 1999, Hoegh-Guldberg 1999). The loss of zooxanthellae and/or photosynthetic pigments is known as coral bleaching and may cause coral death (Glynn \& D'Croz 1990, Glynn et al. 2001) and reef degradation (Hoegh-Guldberg 1999). Incidences of mass coral bleaching have increased since the 1980s and was for the first time recorded on a world-wide scale in 1997-1998. The Great Barrier Reef (GBR) suffered most severely in the summer of 2002, when bleaching occurred on $~ 54 \%$ of its reefs (Berkelmans et al. 2004).

Bleaching susceptibilities are known to differ not only between coral taxa (Hoegh-Guldberg \& Salvat 1995, Marshall \& Baird 2000, Loya et al. 2001) but also between conspecific (Berkelmans \& Oliver 1999, Berkelmans 2002) and congeneric (Coles et al. 1976) populations at geographically distinct locations. This suggests that thermal tolerance is governed by local environmental conditions to which corals have adapted (West \& Salm 2003) or that have caused the expression of distinct phenotypes. The magnitude of differences in bleaching sensitivity of conspecific and geographically distinct coral populations has not previously been determined experimentally. 
It has been shown that the physiological responses of some corals are significantly affected by the type of zooxanthellae harboured (Rowan et al. 1997, Baker 2001, Glynn et al. 2001, Little et al. 2004, Rowan 2004). Furthermore, several studies have shown that some combinations of corals and their symbionts may be environmentally determined (Rowan et al. 1997, Toller et al. 2001, Ulstrup \& van Oppen 2003, Baker et al. 2004, Fabricius et al. 2004). For example, the distribution of symbionts has shown clear patterns of photic zonation resulting in the partitioning of genetically distinct zooxanthellae between irradiance habitats in Montastraea anularis (Rowan et al. 1997) and Acropora spp. (van Oppen et al. 2001, Ulstrup \& van Oppen 2003). Similar results have been found with regard to latitude (Loh et al. 2001, Rodriguez-Lanetty et al. 2001, Savage et al. 2002). It has also been shown that some symbiont genotypes are better suited to withstand elevated thermal exposure than others. For instance, Glynn et al. (2001) showed that Pocillopora damicornis colonies in the far-eastern Pacific harbouring clade D had suffered less from the 1998 mass coral bleaching event than those that associated with symbionts of a different genotype. Furthermore, clade D zooxanthellae inhabiting Pocillopora colonies showed higher photosystem activity than their clade C counterparts during elevated temperatures (Rowan 2004). These studies combined support the notion that clade D generally may be adapted to higher temperatures.

In this study, we examine the intra- and inter-colony distribution of zooxanthella types in 13 populations and the differences in temperature tolerances in 3 latitudinally distinct populations of 2 species of coral; 1 bleaching sensitive (Pocillopora damicornis) and 1 bleaching resistant (Turbinaria reniformis) species. We use variable chlorophyll a fluorescence (Jones et al. 1998, Ralph et al. 2001, Hill et al. 2004) as a measure of photoinactivation (decline in PSII activity), and zooxanthella density (Hoegh-Guldberg \& Smith 1989, Berkelmans \& Willis 1999, Glynn et al. 2001) to study heat stress responses in these corals. By comparing 2 coral species with contrasting bleaching sensitivity we hope to further our understanding of the processes and mechanisms involved in local adaptation to bleaching conditions.

\section{MATERIALS AND METHODS}

Examination of bleaching sensitivity was conducted on populations from the northern, central and southern section of the GBR (Fig. 1, Table 1). Only mid-shelf reefs were targeted to minimise any effects of crossshelf position. However, additional genetic identification of zooxanthella communities was performed on a

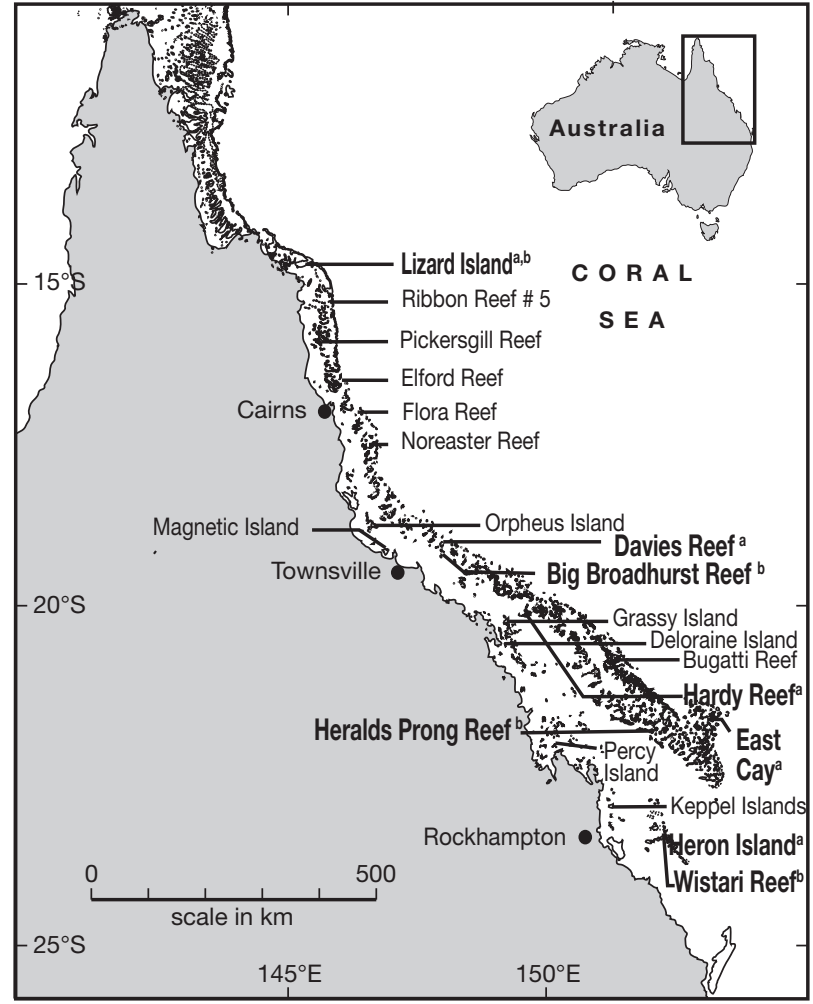

Fig. 1. Map of the Australian eastern sea border showing collection sites: ${ }^{a}$ Locations of sea temperature measurements; ${ }^{\mathrm{b}}$ locations of experimental bleaching samples

wider range of populations, including populations from inner- and mid-shelf locations (Fig. 1, Table 1).

Sampling. Nine coral colonies of each of Pocillopora damicornis and Turbinaria reniformis were sampled in August 2003 at Lizard Island $\left(14.4^{\circ} \mathrm{S}, 144.3^{\circ} \mathrm{E}\right.$, northern GBR), Big Broadhurst Reef $\left(18.3^{\circ} \mathrm{S}, 147.4^{\circ} \mathrm{E}\right.$, central GBR) and Wistari Reef $\left(23.3^{\circ} \mathrm{S}, 151.5^{\circ} \mathrm{E}\right.$, southern GBR) (P. damicornis only). $P$. damicornis generally occurred and was sampled at depths between 1 and $10 \mathrm{~m}$, whereas $T$. reniformis was sampled at depths between 3 and $15 \mathrm{~m}$. T. reniformis could not be found at Wistari Reef and instead was sourced from Heralds Prong Reef $\left(21.3^{\circ} \mathrm{S}, 151.2^{\circ} \mathrm{E}\right.$, southern GBR) (Fig. 1). Corals were maintained in flowing seawater $\left(26^{\circ} \mathrm{C}\right)$ and transported to the Australian Institute of Marine Science (AIMS) in Townsville, where the bleaching sensitivity experiment was carried out.

Sea temperature measurements. To describe the relative climatology across a latitudinal gradient of the GBR, sea temperatures from 5 locations were obtained from the CRC (Cooperative Research Centre) Reef's long-term temperature monitoring program (www. reeffutures.org/topics/bleach/loggers.cfm). Daily averages were calculated from loggers (Dataflow Systems) deployed at 6 to $9 \mathrm{~m}$ depth over a 6 to $8 \mathrm{yr}$ period be- 
Table 1. Pocillopora damicornis and Turbinaria reniformis. Coral collection sites (see also Fig. 1), sample numbers (n), observed frequencies of zooxanthella type(s) present in both coral species (dominant clade in bold), and shelf position are given. Observed single-stranded conformation polymorphism genotype frequencies of clade $\mathrm{A}, \mathrm{C} 1$, and D are $f_{A}, f_{C 1}$ and $f_{D}$, respectively

\begin{tabular}{|c|c|c|c|c|c|c|c|c|c|}
\hline \multirow[t]{2}{*}{ Sampling location } & & \multicolumn{4}{|c|}{ - P. damicornis } & \multicolumn{3}{|c|}{ T. reniformis } & \multirow[t]{2}{*}{ Shelf position } \\
\hline & & $\mathrm{n}$ & $f_{A}$ & $f_{C 1}$ & $f_{D}$ & $\mathrm{n}$ & $f_{C 1}$ & $f_{D}$ & \\
\hline \multicolumn{10}{|l|}{ Northern GBR } \\
\hline \multirow[t]{2}{*}{ Lizard Island } & Sun & 10 & 1 & $10(9)$ & 4 & 10 & 10 & 10 & Mid \\
\hline & Shade & 10 & 1 & $10(9)$ & 4 & 4 & 4 & 4 & \\
\hline \multirow[t]{2}{*}{ Ribbon Reef \# 5} & Sun & 10 & - & 10 & 2 & 2 & 2 & 2 & Outer \\
\hline & Shade & 10 & - & 10 & 2 & 2 & 2 & 2 & \\
\hline \multirow[t]{2}{*}{ Pickersgill Reef } & Sun & 10 & - & 10 & - & 7 & 7 & 7 & Mid \\
\hline & Shade & 9 & - & 9 & - & 7 & 7 & 7 & \\
\hline \multirow[t]{2}{*}{ Elford Reef } & Sun & 9 & - & 9 & - & 7 & 7 & 7 & Mid \\
\hline & Shade & 10 & - & 10 & - & 10 & 10 & 10 & \\
\hline \multirow[t]{2}{*}{ Flora Reef } & Sun & 8 & - & 8 & - & 8 & 8 & 8 & Mid \\
\hline & Shade & 10 & - & 10 & - & 9 & 9 & 9 & \\
\hline \multirow[t]{2}{*}{ Noreaster Reef } & Sun & 10 & - & 10 & 2 & 9 & 9 & 9 & Mid \\
\hline & Shade & 10 & - & 10 & 2 & 10 & 10 & 10 & \\
\hline \multicolumn{10}{|l|}{ Central GBR } \\
\hline \multirow{2}{*}{ Orpheus Island } & Sun & 10 & - & 10 & - & - & - & - & Inner \\
\hline & Shade & 10 & - & 10 & - & - & - & - & \\
\hline \multirow[t]{2}{*}{ Magnetic Island } & Sun & 10 & - & 10 & - & 10 & 10 & - & Inner \\
\hline & Shade & 10 & - & 10 & - & 10 & 10 & - & \\
\hline \multirow[t]{2}{*}{ Big Broadhurst Reef } & Sun & 8 & - & 8 & 3 & 9 & 9 & - & Mid \\
\hline & Shade & 10 & - & 10 & 3 & 8 & 8 & - & \\
\hline \multirow[t]{2}{*}{ Grassy Island } & Sun & - & - & - & - & 10 & 10 & - & Inner \\
\hline & Shade & - & - & - & - & 10 & 10 & - & \\
\hline \multirow[t]{2}{*}{ Deloraine Island } & Sun & 10 & - & 10 & - & - & - & - & Inner \\
\hline & Shade & 9 & - & 9 & - & - & - & - & \\
\hline \multirow[t]{2}{*}{ Bugatti Reef } & Sun & 7 & - & 7 & - & 10 & 10 & - & Mid \\
\hline & Shade & 7 & - & 7 & - & 10 & 10 & - & \\
\hline \multicolumn{10}{|l|}{ Southern GBR } \\
\hline \multirow[t]{2}{*}{ Herald Prong Reef } & Sun & 10 & - & 10 & - & 8 & 8 & 6 & Mid \\
\hline & Shade & 9 & - & 9 & - & 8 & 8 & 6 & \\
\hline \multirow[t]{2}{*}{ Percy Island } & Sun & 10 & - & 10 & - & 10 & 10 & 1 & Inner \\
\hline & Shade & 8 & - & 8 & - & 10 & 10 & 1 & \\
\hline \multirow[t]{2}{*}{ Keppel Islands } & Sun & 10 & - & 10 & - & 10 & 10 & - & Inner \\
\hline & Shade & 7 & - & 7 & - & 10 & 10 & - & \\
\hline \multirow[t]{2}{*}{ Wistari Reef } & Sun & 9 & - & 9 & - & - & - & - & Mid \\
\hline & Shade & 9 & - & 9 & - & - & - & - & \\
\hline
\end{tabular}

tween 1995 and 2005 on the reef slope at Lizard Island $\left(14^{\circ} 41.3^{\prime} \mathrm{S}, 145^{\circ} 26.6^{\prime} \mathrm{E}\right)$, Davies Reef $\left(18^{\circ} 48.4^{\prime} \mathrm{S}\right.$, $\left.147^{\circ} 40.1^{\prime} \mathrm{E}\right)$, Hardy Reef $\left(19^{\circ} 44.0^{\prime} \mathrm{S}, 149^{\circ} 10.0^{\prime} \mathrm{E}\right)$ East Cay $\left(21^{\circ} 28.3^{\prime} \mathrm{S}, 152^{\circ} 34.0^{\prime} \mathrm{E}\right)$ and Heron Island $\left(23^{\circ} 26.6^{\prime} \mathrm{S}, 151^{\circ} 54.7^{\prime} \mathrm{E}\right)$. Davies Reef temperatures were recorded approximately $6 \mathrm{~km}$ from the collection site at Big Broadhurst Reef, while Hardy Reef is located approximately $300 \mathrm{~km}$ north and East Cay approximately $140 \mathrm{~km}$ east (i.e. same latitude), respectively, of our collection site at Heralds Prong Reef. Heron Island temperatures were recorded approximately $3 \mathrm{~km}$ from our collecting site at Wistari Reef. A 10 d smoothing function was applied to the data to highlight seasonal patterns. The temperature at collection sites corresponded to the averaged temperature observed in August as represented in Fig. 2.

Experimental procedure. The corals were placed in large indoor holding tanks with flow-through seawater

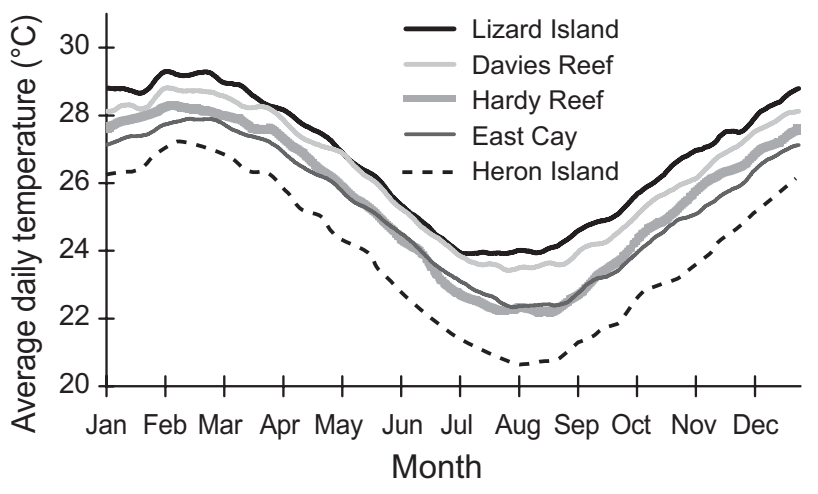

Fig. 2. Average daily temperatures for the reef slope (6 to $9 \mathrm{~m}$ depth) for each day (48 measurements per d) at Lizard Island, Davies Reef, Hardy Reef, East Cay and Heron Island. A $10 \mathrm{~d}$ smoothing function is applied to indicate the general trend in yearly temperatures 
and acclimated to the control conditions for 2 wk prior to heating. Four experimental holding tanks, each containing $1200 \mathrm{l}$ of unfiltered seawater, were fitted with 2 heating elements $(2.4 \mathrm{kw}$ titanium, Thermal Electric Elements). Bleaching temperatures $\left(29^{\circ} \mathrm{C}, 31^{\circ} \mathrm{C}, 33^{\circ} \mathrm{C}\right)$ were attained by ramping at $0.2^{\circ} \mathrm{C} / \mathrm{h}$. The 3 experimental bleaching temperatures and 1 control temperature $\left(26^{\circ} \mathrm{C}\right)$ were maintained for 2 wk and subsequently experimental treatments were reduced to $26^{\circ} \mathrm{C}$ for recovery for an additional $2 \mathrm{wk}$. Temperature of the supply water was computer-controlled to target temperature \pm 0.02 to $0.09^{\circ} \mathrm{C} \mathrm{SD}$ (averaged and logged at 10 min intervals) (Turner et al. 2002). Temperature variation within the holding tanks was minimised by circulation of water $\left(\sim 2000 \mathrm{l} \mathrm{h}^{-1}\right)$ via submersible pumps (SICCE ULTRA 7000). Heated seawater was pumped from each holding tank into 3 replicate 351 bins containing coral fragments. Metal halide lamps (400 watts:BLC, $10000^{\circ} \mathrm{K}$ ) provided a spectral output suitable for photosynthesis. Coral explants were exposed daily to approximately $300 \mu \mathrm{mol}$ photons $\mathrm{m}^{-2} \mathrm{~s}^{-1}$ (LiCor) for $12 \mathrm{~h}$ followed by $12 \mathrm{~h}$ of darkness. One fragment from each of 9 Pocillopora damicornis and Turbinaria reniformis colonies from each of the 3 populations were represented in each bin.

Three additional samples of Pocillopora damicornis and Turbinaria reniformis from northern (Lizard Island), central (Big Broadhurst Reef) and southern ( $P$. damicornis, Wistari Reef; T. reniformis, Heralds Prong Reef) GBR were placed in each of the 3 bins $(n=9)$ belonging to each of the 4 temperature treatments to verify the progression of bleaching by determining the density of zooxanthellae inside the coral tissue. One sample from each species in each of the bins was subsampled $(\mathrm{n}=3)$ before heating $(\mathrm{t}=0 \mathrm{~d}, \mathrm{n}=12)$, immediately after heating $(\mathrm{t}=14 \mathrm{~d}, \mathrm{n}=3)$ and at the end of the recovery period $(t=28 d, n=3)$. The approximate number of Symbiodinium cells in the samples was calculated from the average of 8 replicate haemocytometer counts and standardised to the liquid volume in which they were extracted and related to the coral surface area using the wax weight method described in Stimson (1997). The percentage change in zooxanthella density of explants exposed to 29 and $31^{\circ} \mathrm{C}$ in relation to those exposed to $26^{\circ} \mathrm{C}$ was calculated.

Single-point measurements of dark-adapted maximum quantum yield of PSII $\left(F_{\mathrm{v}} / F_{\mathrm{m}}\right)$ (e.g. Schreiber 2004) were used to test the photosynthetic health (photochemical efficiency) of the zooxanthellae of all coral fragments ( $n=27$ per species per bin) throughout the pre-bleaching (data not shown), bleaching and recovery periods. Maximum quantum yield in corals (darkadapted) was determined using a Diving-PAM fluorometer (Walz) after at least $8 \mathrm{~h}$ of darkness. Samples were illuminated with $<2 \mu \mathrm{mol}$ photons $\mathrm{m}^{-2} \mathrm{~s}^{-1}$ during sampling. The percentage change in $F_{\mathrm{v}} / F_{\mathrm{m}}$ of explants measured every $2 \mathrm{~d}$ was calculated in relation to preheating measurements. No samples were replaced in the statistical analysis. The assessment of death among explants was based on combined observations of fluorescence signals, lack of coral tissue movement and algal overgrowth.

Genetic identification of zooxanthellae in field colonies. Zooxanthellae harboured in sun- and shadeexposed tissues of 10 collected explants from each of the 3 experimental populations of both Pocillopora damicornis and Turbinaria reniformis were genetically identified. Only 9 of those were used in the bleaching sensitivity experiments. Hence, intra-colonial variability of zooxanthellae communities was assessed by sampling top and basal parts of colonies, which showed clear differences in colouration. Some colonies of T. reniformis did not show morphologies which had basal parts but were creeping partially up and under an overhang. In such cases, shaded samples were collected from these parts of the colonies.

To obtain a wider regional overview of symbiont types in these coral species, $P$. damicornis was collected from an additional 12 reefs and T. reniformis from an additional 10 reefs from north to south as follows: Ribbon Reef \# $5\left(15.2^{\circ} \mathrm{S}, 145.3^{\circ} \mathrm{E}\right)$, Elford Reef $\left(16.6^{\circ} \mathrm{S}, 146.3^{\circ} \mathrm{E}\right)$, Flora Reef $\left(17.1^{\circ} \mathrm{S}, 146.2^{\circ} \mathrm{E}\right)$, Noreaster Reef $\left(17.5^{\circ} \mathrm{S}, 146.4^{\circ} \mathrm{E}\right)$, Orpheus Island $\left(18^{\circ} 35^{\prime} \mathrm{S}\right.$, $\left.146^{\circ} 20^{\prime} \mathrm{E}\right)$ (P. damicornis), Magnetic Island $\left(19^{\circ} 15^{\prime} \mathrm{S}\right.$, $\left.146^{\circ} 50^{\prime} \mathrm{E}\right)$, Grassy Island $\left(20.1^{\circ} \mathrm{S}, 148.3^{\circ} \mathrm{E}\right)$, Deloraine Island $\left(20.9^{\circ} \mathrm{S}, 149.4^{\circ} \mathrm{E}\right)$, Bugatti Reef $\left(20.1^{\circ} \mathrm{S}, 150.2^{\circ} \mathrm{E}\right)$, Heralds Prong Reef $\left(21.3^{\circ} \mathrm{S}, 151.2^{\circ} \mathrm{E}\right)($ P. damicornis), Percy Island $\left(21.4^{\circ} \mathrm{S}, 150.1^{\circ} \mathrm{E}\right)$, Keppel Islands $\left(23.1^{\circ} \mathrm{S}\right.$, $150.6^{\circ} \mathrm{E}$ ) (Fig. 1, Table 1). The sampling locations covered $1400 \mathrm{~km}$ in latitude as well as inner-, mid-, and outer shelf locations (Fig. 1, Table 1).

DNA was extracted from the corals using the DNeasy tissue extraction kit (Qiagen). The zooxanthella ribosomal DNA internal transcribed spacer 1 (ITS1) was PCR amplified as described in van Oppen et al. (2001), using a fluorescently labeled forward primer. Single-stranded conformation polymorphism (SSCP) (Sunnucks et al. 2000) analysis and DNA sequence analysis was used to determine the genetic identity of the zooxanthella samples. For SSCP analysis, amplicons were denatured at $98^{\circ} \mathrm{C}$ and snapcooled on ice to allow the single-stranded DNA (ssDNA) to fold back onto itself. The products were run on a $4 \%$ non-denaturing polyacrylamide gel and visualized using the GelScan2000 system (Corbett Research) to obtain SSCP profiles. PCR products that resulted in different SSCP profiles were sequenced as described in van Oppen et al. (2001) and compared to existing sequences stored in Genbank (www.ncbi. nlm.nih.gov). 
Statistical analyses. Comparisons of zooxanthella densities prior to, after heating and after recovery of latitudinally distinct populations of Pocillopora damicornis and Turbinaria reniformis were tested using 1-way ANOVA. Since all explants of both species died during the 2 weeks of exposure to $33^{\circ} \mathrm{C}$, only samples which were exposed to $29^{\circ} \mathrm{C}$ and $31^{\circ} \mathrm{C}$ were statistically analysed. Assumptions of normality and of homogeneity of variances were tested using Smirnov-Komolgorov's and Levene's test, respectively. The non-parametric Kruskal-Wallis test was performed where normality and equal variance were not achieved.

Factorial univariate, repeated measured analysis of variance was performed on $F_{\mathrm{v}} / F_{\mathrm{m}}$ measurements in order to determine the relationship of temperature treatments with latitudinally distinct populations of Pocillopora damicornis and Turbinaria reniformis. Day was analysed as within-subject factor as they were repeated measures on the same colony and Temp (temperature) and Location were analysed as between-subject factor (see Table $4 \& 5$ ). Bleaching and recovery periods were analysed separately. Where ANOVA determined a significant difference, Box's test of equality of covariance matrices was used to test the homogeneity of variances across groups. Also, the assumption of sphericity was tested. Where assumptions of the analyses were not met, the Greenhouse-Geisser adjustment was performed (Quinn \& Keough 2002). Tukey's multiple comparisons were used to establish independency between treatments, populations and species. All analyses were performed using SPSS software v11.0.0.

\section{RESULTS}

\section{Temperature range}

Fig. 2 shows the daily sea water temperature averages for the reef slope (6 to $9 \mathrm{~m}$ depth) for each day of the year from Lizard Island, Davies Reef (our surrogate for Big Broadhurst Reef), Hardy Reef and East Cay (our surrogates for Heralds Prong Reef) and Heron Island (our surrogate for Wistari Reef). Although we were unable to obtain data in the near vicinity of Heralds Prong Reef it is a reasonable assumption that the temperature regime at this location would fall within the range of that observed at Heron Island, East Cay and Hardy Reef. The annual temperature variation corresponds with latitude. Heron Island shows the lowest winter and summer sea surface temperatures $\left(20.7^{\circ} \mathrm{C}\right.$ and $27.2^{\circ} \mathrm{C}$, respectively), whereas Lizard Island shows the highest winter and summer daily average sea surface temperatures $\left(23.8^{\circ} \mathrm{C}\right.$ and $29.3^{\circ} \mathrm{C}$, respectively). Although Davies Reef is located roughly equidistant from Lizard and Heron Island, its temperature range is close to that at Lizard Island $\left(23.4\right.$ to $\left.28.8^{\circ} \mathrm{C}\right)$, whereas Hardy Reef and East Cay exhibit average temperatures between those of Davies Reef and Heron Island (Fig. 2).

There was no significant variation between holding tanks containing $26^{\circ} \mathrm{C}$ seawater in the pre-heating and recovery phase $(p<0.05)$. Similarly, temperatures measured continuously in holding tanks during heating showed no overlap in calculated 95 percentiles (data not shown). Therefore, the variation within temperature treatments in the pre-heating, heating and recovery phase was within satisfactory precision.

\section{Mortality}

A comparison of accumulated mortality (\%) between Pocillopora damicornis and Turbinaria reniformis confirmed that $P$. damicornis is the more bleaching sensitive species (Fig. 3). P. damicornis explants from Wistari Reef showed the earliest and severest mortality for all temperature treatments (Fig. 3A). At $29^{\circ} \mathrm{C}$, initial mortality of Wistari Reef explants was encountered after $5 \mathrm{~d}$ (Fig. 3A), whereas initial mortality at 31 and $33^{\circ} \mathrm{C}$ occurred after $1 \mathrm{~d}$ (Fig. 3A). Complete mortality of experimental explants of $P$. damicornis was reached after 5 to $7 \mathrm{~d}$ at $33^{\circ} \mathrm{C}$ for corals from all locations (Fig. 3A). P. damicornis explants derived from Lizard Island kept at $31^{\circ} \mathrm{C}$ showed lowest total mortality and those at $33^{\circ} \mathrm{C}$ exhibited the most delayed onset of mortality (black bars, Fig. 3A). Mortality among P. damicornis explants continued to rise throughout the recovery period (Fig. 3A). The highest mortality during the recovery period occurred in Big Broadhurst Reef explants (22\%) and Wistari Reef $(29 \%)$ previously exposed to $31^{\circ} \mathrm{C}$ (Fig. 3A). Throughout the heating and recovery period, accumulated mortality among $P$. damicornis explants maintained at $26^{\circ} \mathrm{C}$ was 18 to $29 \%$ (Fig. 3A).

Mortality of Turbinaria reniformis was only observed among explants exposed to $33^{\circ} \mathrm{C}$ (Fig. 3B). Complete mortality $(100 \%)$ was reached after $13 \mathrm{~d}$ of exposure to $33^{\circ} \mathrm{C}$ for all 3 locations (Fig. 3B). There was little difference in the relative increase in mortality between locations, although explants from Heralds Prong Reef suffered $22 \%$ more mortality than those from Lizard Island and Big Broadhurst Reef after $9 \mathrm{~d}$ of exposure to $33^{\circ} \mathrm{C}$. No mortality occurred among Turbinaria reniformis explants during the recovery period following heating to 29 and $31^{\circ} \mathrm{C}$ (Fig. 3B), indicating that the heating period did not have a delayed effect.

\section{Zooxanthella density}

Pocillopora damicornis explants from Wistari Reef exhibited the highest $(p<0.001)$ zooxanthella density 

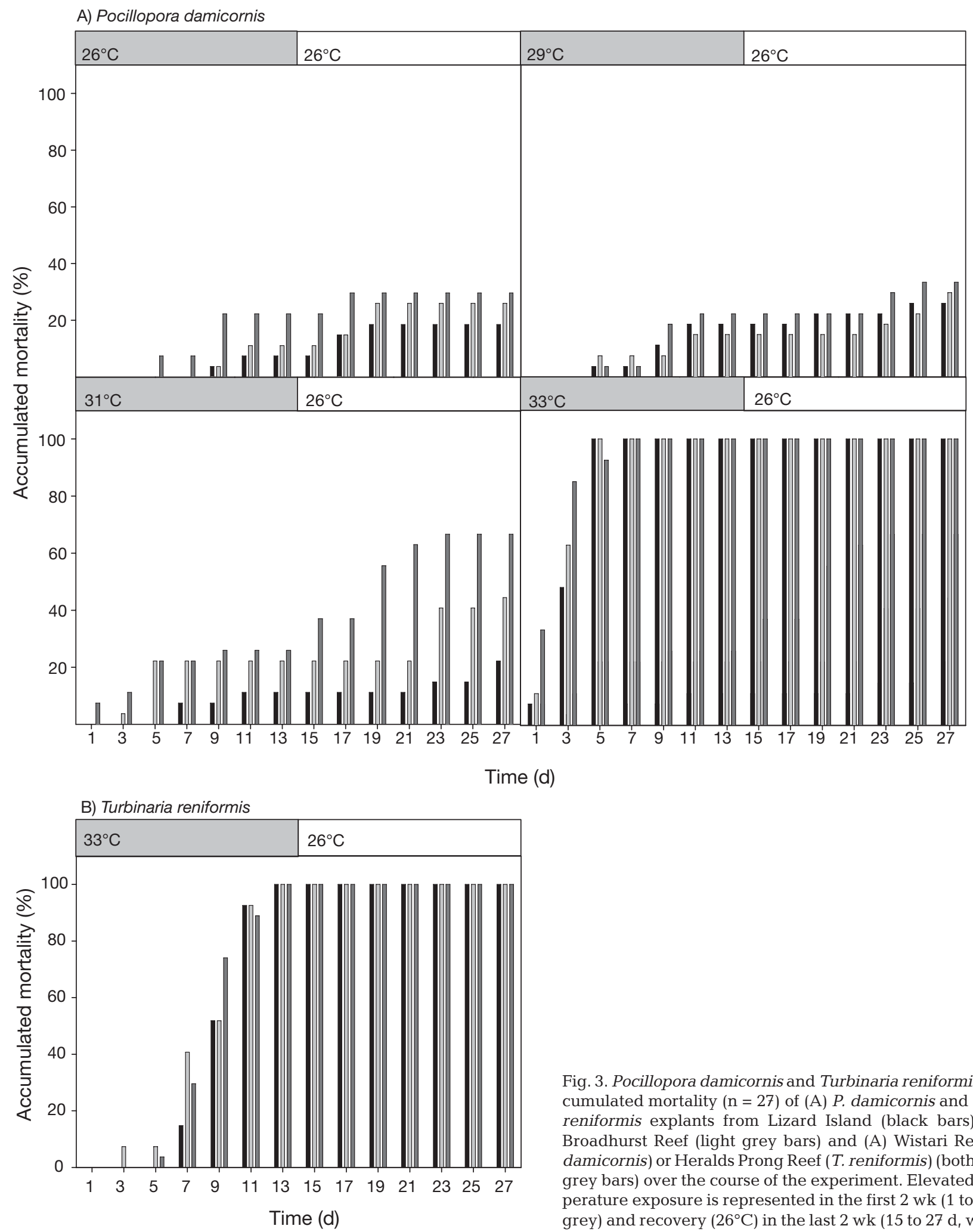

Fig. 3. Pocillopora damicornis and Turbinaria reniformis. Accumulated mortality $(\mathrm{n}=27$ ) of $(\mathrm{A}) P$. damicornis and (B) $T$. reniformis explants from Lizard Island (black bars), Big Broadhurst Reef (light grey bars) and (A) Wistari Reef ( $P$. damicornis) or Heralds Prong Reef (T. reniformis) (both dark grey bars) over the course of the experiment. Elevated temperature exposure is represented in the first $2 \mathrm{wk}(1$ to $13 \mathrm{~d}$, grey) and recovery $\left(26^{\circ} \mathrm{C}\right)$ in the last 2 wk (15 to $27 \mathrm{~d}$, white)

followed by Lizard Island and Broadhurst Reef (Wistari Reef > Lizard Island > Big Broadhurst Reef; Table 2). Zooxanthella density of control explants of $P$. damicornis from Big Broadhurst Reef exposed to $26^{\circ} \mathrm{C}$ in-

creased significantly $(\mathrm{p}<0.05)$ throughout the experimental period (Table 2). No density counts are available for explants exposed to $33^{\circ} \mathrm{C}$ as they all died. P. damicornis explants from Wistari Reef showed a sig- 
nificant decline in zooxanthella densities when exposed to $31^{\circ} \mathrm{C}$, as well as after the following recovery period (Fig. 4A). No significant change in zooxanthella density was observed between the heating and recovery period for all geographically distinct populations exposed to both 29 and $31^{\circ} \mathrm{C}$ (Fig. 4A).

No decline in zooxanthella density in control explants of Turbinaria reniformis was observed during the experimental period (Table 2). The decline in zooxanthella density in $T$. reniformis explants from all populations was significant after exposure to $31^{\circ} \mathrm{C}$ (Fig. 4B). Zooxanthella density in Lizard Island explants following recovery from $29^{\circ} \mathrm{C}$ was significantly greater $(\mathrm{p}<0.05)$ than before experimental elevation of the temperature (Fig 4B). Of all explants exposed to $31^{\circ} \mathrm{C}$ only those from Lizard Island showed zooxanthella densities similar to pre-heating levels (Fig. 4B).
Heralds Prong Reef explants exposed to $31^{\circ} \mathrm{C}$ showed the greatest decline in zooxanthella density including those measured after the recovery period.

Table 2. Zooxanthella density (numbers of cells $\times 10^{6} \mathrm{~cm}^{-2}$ surface area, $\pm \mathrm{SE}$ ) of controls $\left(26^{\circ} \mathrm{C}\right)$ prior to experimental heating $(t(\mathrm{~d})=0$ : 1 replicate in each of 3 bins of 4 experimental temperature tanks, $\mathrm{n}=12)$, after heating $(t=14: 1$ replicate in each of 3 bins, $n=3)$ and after recovery $(t=28$ : 1 replicate in each of 3 bins, $\mathrm{n}=3$ ) in northern (Lizard Island), central (Big Broadhurst Reef) and southern (Pocillopora damicornis, Wistari Reef; Turbinaria reniformis, Heralds Prong Reef) GBR. Asterisk indicates statistical significance. ns: not significant; -: not analysed

\begin{tabular}{|lccccc|}
\hline & $t(\mathrm{~d})$ & Northern GBR & Central GBR & Southern GBR & p-value \\
\hline P. damicornis & 0 & $0.54 \pm 0.06$ & $0.32 \pm 0.05$ & $1.01^{*} \pm 0.01$ & $<0.001$ \\
& 14 & $0.52 \pm 0.01$ & $0.36 \pm 0.03$ & $0.53 \pm 0.02$ & - \\
& 28 & $0.43 \pm 0.09$ & $0.91^{*} \pm 0.08$ & $0.53 \pm 0.03$ & - \\
p-value & & $\mathrm{ns}$ & $<0.05$ & $\mathrm{~ns}$ & \\
& & & & & \\
T. reniformis & 0 & $0.59 \pm 0.08$ & $0.45 \pm 0.03$ & $0.43 \pm 0.05$ & $\mathrm{~ns}$ \\
& 14 & $0.54 \pm 0.03$ & $0.42 \pm 0.01$ & $0.31 \pm 0.08$ & - \\
p-value & 28 & $0.37 \pm 0.04$ & $0.31 \pm 0.03$ & $0.35 \pm 0.03$ & - \\
& & $\mathrm{ns}$ & $\mathrm{ns}$ & $\mathrm{ns}$ & \\
\hline
\end{tabular}

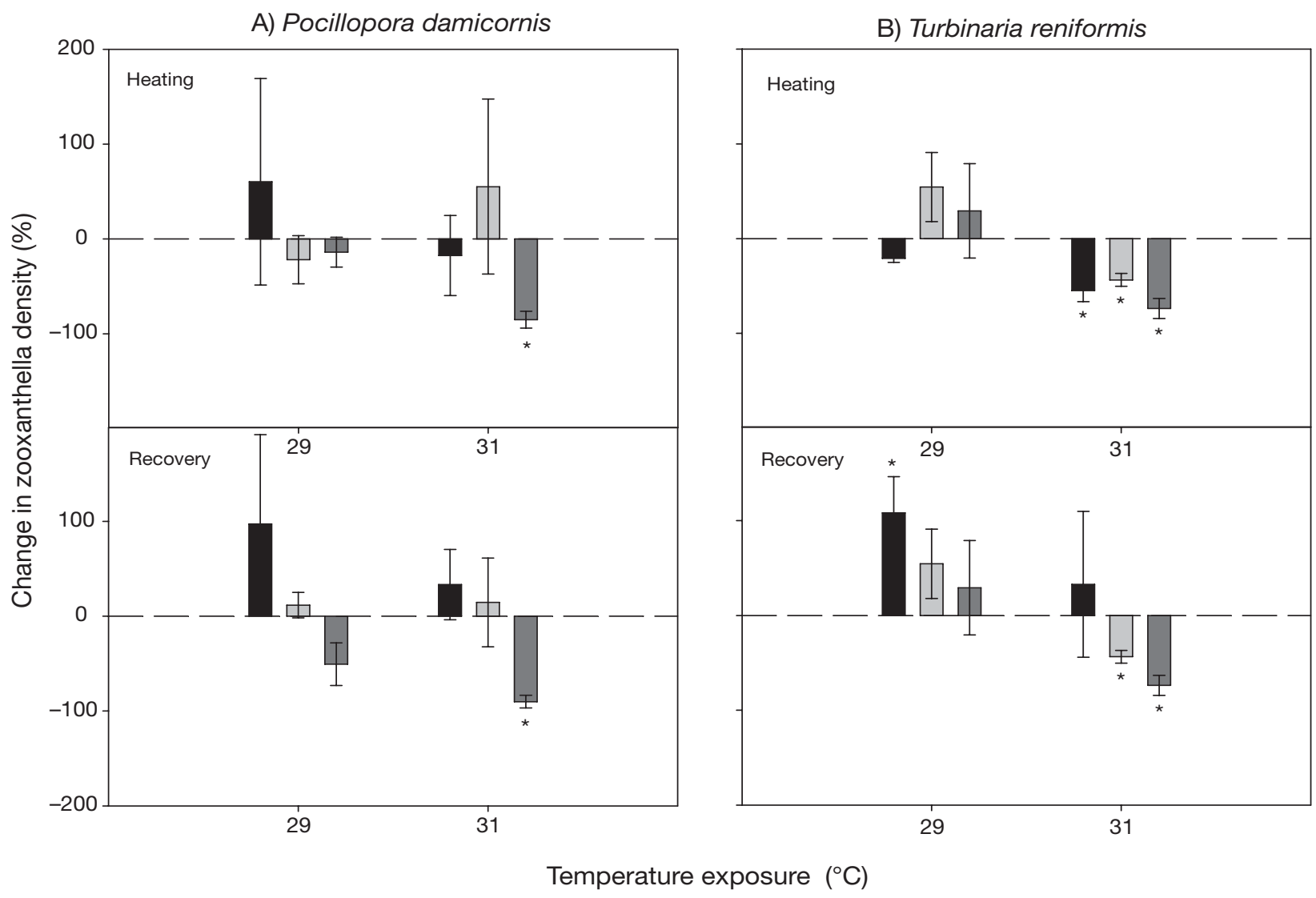

Fig. 4. Pocillopora damicornis and Turbinaria reniformis. Relative change (\%) of zooxanthella density $\left(10^{6} \mathrm{~cm}^{-2}\right)$ in relation to controls of (A) P. damicornis and (B) T. reniformis explants from Lizard Island (black bars), Big Broadhurst Reef (light grey bars) and Wistari Reef (P. damicornis) or Heralds Prong Reef (T. reniformis) (both dark grey bars) after 2 wk of exposure to elevated temperatures $\left(29\right.$ and $31^{\circ} \mathrm{C}$ ) and 2 wk of recovery. Significant differences were calculated by testing between sites at specific temperatures. Averages are shown $(n=3)$ including \pm SE bars. Significant differences $(p<0.05)$ are marked by an asterisk 


\section{Photochemical efficiency $\left(F_{\mathrm{v}} / F_{\mathrm{m}}\right)$}

\section{Pocillopora damicornis}

No significant differences were observed in initial $F_{\mathrm{v}} / F_{\mathrm{m}}$ measurements between populations (Table 3 ). Control explants $\left(26^{\circ} \mathrm{C}\right)$ showed variable change in $F_{\mathrm{v}} / F_{\mathrm{m}}$ over time ranging between 2 and $29 \%$ during the 4 experimental wk (Fig. 5A[a]). No significant interactions between day and location were observed in the change of $F_{\mathrm{v}} / F_{\mathrm{m}}$ measurements over time $(\mathrm{p}=$ 0.087, Table 4a) suggesting that the origin of explants did not influence the rate of bleaching in Pocillopora damicornis. However, the 3-way interaction between day, temperature and location ( $\mathrm{p}<0.001$, Table 4a) and between subject analysis of temperature ( $p<$ 0.001, Table 4a) suggest that the experimental temperature exposure does influence decline in $F_{\mathrm{v}} / F_{\mathrm{m}}$ measurements. Post hoc analysis identified differences in $F_{\mathrm{v}} / F_{\mathrm{m}}$ measurements when explants were exposed to 31 and $33^{\circ} \mathrm{C}$. Between subject analysis of location showed significant differences at these temperatures. Thus, post hoc analysis identified explants from Wistari Reef as being most sensitive to high temperature exposure $(5 \mathrm{~A}[\mathrm{c}, \mathrm{d}])$. Explants from Lizard Island and Big Broadhurst Reef showed slower initial declines in $F_{\mathrm{v}} / F_{\mathrm{m}}$ than explants from Wistari Reef. However, explants from Lizard Island were the first to bleach completely after $5 \mathrm{~d}$, whereas explants from Big Broadhurst and Wistari Reefs resisted complete bleaching for $7 \mathrm{~d}$ (Fig. 5A[d]).

Between subject analysis showed that the decline in $F_{\mathrm{v}} / F_{\mathrm{m}}$ observed during the recovery period correlated with previous temperature exposure $(p<0.001$, Table $4 \mathrm{~b}$ ). The continual decline during the recovery period of explants exposed to $31^{\circ} \mathrm{C}$ (Fig. 5A[c]) was greatest in Wistari Reef explants ( $\mathrm{p}<0.001$, Table $4 \mathrm{a}$ ). Thus, at $31^{\circ} \mathrm{C}$ the sequence of bleaching susceptibility between Pocillopora damicornis populations was Wistari Reef $>$ Big Broadhurst Reef $>$ Lizard Island as indicated by the level of $F_{\mathrm{v}} / F_{\mathrm{m}}$ at the end of the recovery period (Fig. 5A[c]).
Table 3. Absolute photochemical efficiency $\left(F_{\mathrm{v}} / F_{\mathrm{m}} \pm 1 \mathrm{SE} ; \mathrm{n}=27\right)$ prior to experimental heating of explants in northern (Lizard Island), central (Big Broadhurst Reef) and southern (Pocillopora damicornis, Wistari Reef; Turbinaria reniformis, Heralds Prong Reef) GBR. Values with different superscript letters were significantly different; ns: not significant

\begin{tabular}{|lrrrc|}
\hline & Northern GBR & Central GBR & Southern GBR & p-value \\
\hline P. damicornis & $0.684 \pm 0.008$ & $0.667 \pm 0.008$ & $0.663 \pm 0.006$ & ns \\
T. reniformis & $0.606^{\mathrm{a}} \pm 0.004$ & $0.574^{\mathrm{b}} \pm 0.009$ & $0.635^{\mathrm{c}} \pm 0.007$ & $<0.01$ \\
\hline
\end{tabular}

\section{Turbinaria reniformis}

All 3 populations showed initial significant differences $(<0.01)$ between populations in $F_{\mathrm{v}} / F_{\mathrm{m}}$ (Table 3 ). Control explants $\left(26^{\circ} \mathrm{C}\right)$ showed minimal change (both increases and decreases) in $F_{\mathrm{v}} / F_{\mathrm{m}}$ over time ranging between 4 and $8 \%$ during the 4 experimental

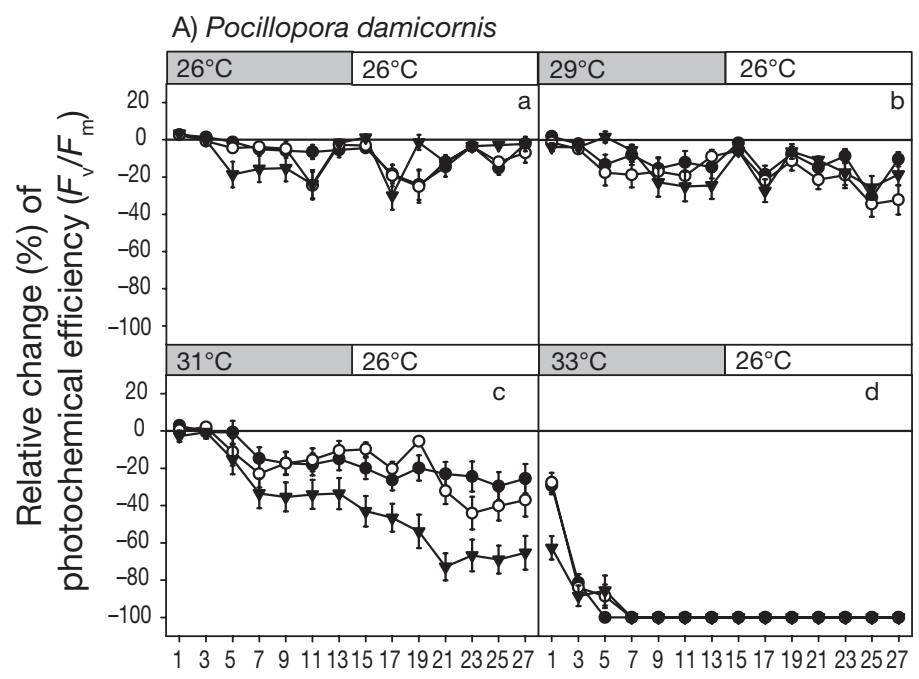

B) Turbinaria reniformis

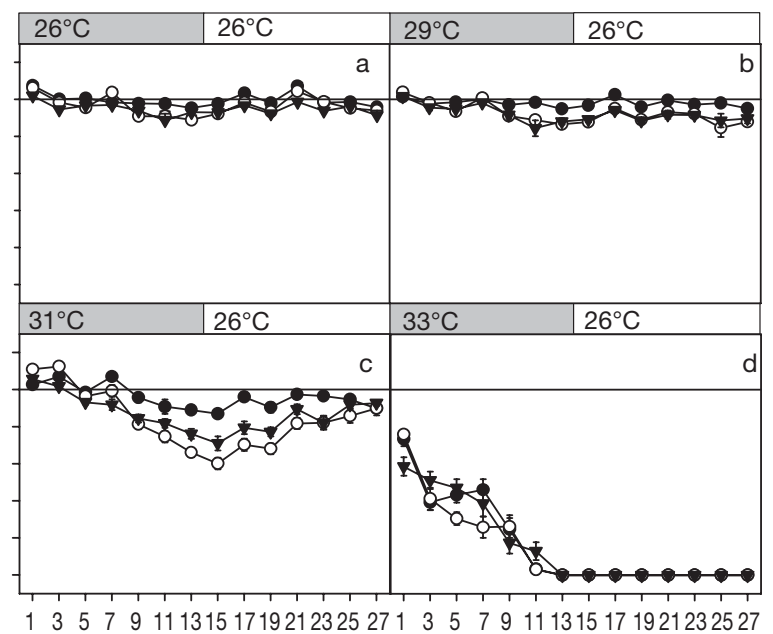

Time (d)

Fig. 5. Pocillopora damicornis and Turbinaria reniformis. Average relative change $(\%)$ of photochemical efficiency $\left(F_{\mathrm{v}} / F_{\mathrm{m}}\right)$ in relation to pre-bleaching responses ( $\mathrm{n}=27 \pm 1 \mathrm{SE}$ ) of $(\mathrm{A})$ P. damicornis and (B) T. reniformis explants from Lizard Island (solid circles), Big Broadhurst Reef (white circles) and Wistari Reef ( $P$. damicornis) or Heralds Prong Reef ( $T$. reniformis) (both triangles). Two wk of (a) control and (b-d) bleaching treatments are shown (1 to $13 \mathrm{~d}$, grey) followed by 2 wk of recovery (15 to $27 \mathrm{~d}$, white) 
Table 4. Univariate analyses of (a) heating and (b) recovery of Pocillopora damicornis testing the hypothesis that changes in $F_{\mathrm{v}} / F_{\mathrm{m}}$ following a change in temperature are independent of sampling origin. Day (d, within-subject factor): 0, 1, 3, 5, 7, 9, 11, 13, 15,

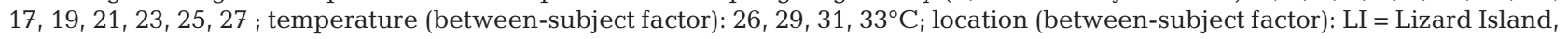
$\mathrm{BBR}=$ Big Broadhurst Reef, WR $=$ Wistari Reef

\begin{tabular}{|c|c|c|c|c|c|c|c|}
\hline Source of variation & SS & df & $\mathrm{df}^{\mathrm{adj}}$ & MS & $F$ & $\mathrm{p}^{\mathrm{a}}$ & Tukey's \\
\hline \multicolumn{8}{|c|}{ a) ANOVA for repeated measures } \\
\hline \multicolumn{8}{|c|}{ Within subjects } \\
\hline Day & 23.494 & 7 & 5.402 & 4.349 & 171.043 & $<0.001$ & $\mathrm{~d} 1>\mathrm{d} 3>\mathrm{d} 9$ \\
\hline Day $\times$ Location & 0.446 & 14 & 10.803 & $4.132 \times 10^{-2}$ & 1.625 & 0.087 & \\
\hline Day $\times$ Temp & 22.733 & 21 & 16.205 & 1.403 & 55.169 & $<0.001$ & \\
\hline Day $\times$ Temp $\times$ Location & 2.176 & 42 & 32.409 & $6.713 \times 10^{-2}$ & 2.640 & $<0.001$ & \\
\hline \multicolumn{8}{|l|}{ Between subjects } \\
\hline Temp & 97.519 & 3 & & 32.506 & 727.665 & $<0.001$ & $26^{\circ} \mathrm{C}, 29^{\circ} \mathrm{C}>31^{\circ} \mathrm{C}>33^{\circ} \mathrm{C}$ \\
\hline Location & 1.270 & 2 & & 0.635 & 14.210 & $<0.001$ & LI, $\mathrm{BBR}>\mathrm{WR}$ \\
\hline Temp $\times$ Location & 345 & 6 & & $5.753 \times 10^{-2}$ & 1.288 & 0.262 & \\
\hline \multicolumn{8}{|c|}{ b) ANOVA for repeated measures } \\
\hline \multicolumn{8}{|c|}{ Within subjects } \\
\hline Day & 2.268 & 7 & 5.739 & 0.395 & 13.291 & $<0.001$ & $\mathrm{~d} 15>\mathrm{d} 17>\mathrm{d} 23>\mathrm{d} 25>\mathrm{d} 27$ \\
\hline Day $\times$ Location & 0.524 & 14 & 11.478 & $4.567 \times 10^{-2}$ & 1.535 & 0.109 & \\
\hline Day $\times$ Temp & 3.520 & 21 & 17.217 & 0.204 & 6.870 & $<0.001$ & \\
\hline Day $\times$ Temp $\times$ Location & 1.616 & 42 & 34.434 & $4.694 \times 10^{-2}$ & 1.577 & 0.018 & \\
\hline \multicolumn{8}{|l|}{ Between subjects } \\
\hline Temp & 149.893 & 3 & & 49.964 & 924.336 & $<0.001$ & $26^{\circ} \mathrm{C}>29^{\circ} \mathrm{C}>31^{\circ} \mathrm{C}$ \\
\hline Location & 1.657 & 2 & & 0.828 & 15.323 & $<0.001$ & LI, BBR>WR \\
\hline Temp $\times$ Location & 16.865 & 6 & & 0.894 & 16.531 & $<0.001$ & \\
\hline
\end{tabular}

weeks (Fig. 5B[a]). Significant 2- and 3-way interactions were observed between day, location and temperature during bleaching and recovery $(p<0.001$, Table 5a,b). Between subject analysis and Tukey's post hoc test showed that changes in $F_{\mathrm{v}} / F_{\mathrm{m}}$ over time of 26 and $29^{\circ} \mathrm{C}$ was similar, whereas 31 and $33^{\circ} \mathrm{C}$ showed progressively greater declines of $F_{\mathrm{v}} / F_{\mathrm{m}}(\mathrm{p}<$ 0.001, Table 5a). After 9 d, Big Broadhurst and Heralds Prong Reef explants showed a greater decline than Lizard Island explants (Fig. 5B[c]). By the end of the $31^{\circ} \mathrm{C}$ exposure period, Big Broadhurst Reef explants showed the greatest decline followed by Heralds Prong Reef explants (Fig. 5B[c], Table 5a). All Turbinaria reniformis explants survived heating to $33^{\circ} \mathrm{C}$ for $11 \mathrm{~d}$ (Fig. $5 \mathrm{~B}[\mathrm{~d}]$ ) and thus showed a less rapid decline in $F_{\mathrm{v}} / F_{\mathrm{m}}$ compared to Pocillopora damicornis (Fig. 5A[d]).

No further decline in $F_{\mathrm{v}} / F_{\mathrm{m}}$ of Turbinaria reniformis explants exposed to 26,29 and $31^{\circ} \mathrm{C}$ was observed during recovery (Fig. 5B[a-c]). Between subject analysis of temperature showed a significant difference between recovery at different temperatures. Tukey's post hoc test identified the recovery as being correlated to previous temperature exposure $(\mathrm{p}<$ 0.001, Table 5b). Explants from Lizard Island showed the most rapid recovery followed by explants from Heralds Prong Reef ( $p<0.001$, Table 5b, Fig. 5B[c]).

\section{Genotyping of zooxanthellae}

The results show that colonies used to examine bleaching sensitivity harboured predominantly Symbiodinium strain $\mathrm{C} 1$, except for Turbinaria reniformis explants from Lizard Island which were dominated by Symbiodinium clade D. Pocillopora damicornis colonies collected from all sites along the latitudinal gradient were dominated by Symbiodinium clade C, specifically, the C1 strain as described in van Oppen et al. (2001), GenBank Accession \# AY457958 (Table 1). The faint gel bands observed in this study using SSCP analysis represented a minimum of 5 to $10 \%$ relative abundance of zooxanthella strains present in the sample (Fabricius et al. 2004). Thus, Symbiodinium clade D (Genbank Accession \# AY327073) co-occurred with clade $\mathrm{C}$ in upper and lower surfaces of 2 colonies from Noreaster and Ribbon Reef \# 5, 3 colonies from Big Broadhurst Reef and 4 colonies from Lizard Island. One P. damicornis colony at Lizard Island was found to harbour clade A zooxanthellae in both upper and lower surfaces in addition to clade $\mathrm{C}$. In this colony, clade A (GenBank Accession \# AF380513) was the dominant type. None of the sampled colonies exhibited any intra-colony differences in zooxanthella types between upper and lower surfaces. 
Table 5. Univariate analyses of (a) heating and (b) recovery of Turbinaria reniformis testing the hypothesis that changes in $F_{\mathrm{v}} / F_{\mathrm{m}}$ following a change in temperature are independent of sampling origin. Day (d, within-subject factor): 0, 1, 3, 5, 7, 9, 11 13, 15, 17, 19, 21, 23, 25, 27; temperature (between-subject factor): 26, 29, 31, 33 ${ }^{\circ} \mathrm{C}_{i}$ location (between-subject factor): LI = Lizard Island, $\mathrm{BR}=$ Big Broadhurst Reef, HPR $=$ Heralds Prong Reef

\begin{tabular}{|c|c|c|c|c|c|c|c|}
\hline Source of variation & SS & $\mathrm{df}$ & $\mathrm{df}^{\text {adj }}$ & MS & $F$ & $\mathrm{p}^{\mathrm{a}}$ & Tukey's \\
\hline \multicolumn{8}{|c|}{ a) ANOVA for repeated measures } \\
\hline \multicolumn{8}{|c|}{ Within subjects } \\
\hline Day & 14.720 & 7 & 4.661 & 3.158 & 302.277 & $<0.001$ & $\mathrm{~d} 1>\mathrm{d} 5>\mathrm{d} 7>\mathrm{d} 9>\mathrm{d} 11>\mathrm{d} 13$ \\
\hline Day $\times$ Location & 0.376 & 14 & 9.322 & $4.037 \times 10^{-2}$ & 3.864 & $<0.001$ & \\
\hline Day $\times$ Temp & 16.078 & 21 & 13.984 & 1.150 & 110.054 & $<0.001$ & \\
\hline Day $\times$ Temp $\times$ Location & 1.011 & 42 & 27.967 & $3.614 \times 10^{-2}$ & 3.459 & $<0.001$ & \\
\hline \multicolumn{8}{|l|}{ Between subjects } \\
\hline Temp & 46.624 & 3 & & 15.541 & 1106.12 & $<0.001$ & $26^{\circ} \mathrm{C}, 29^{\circ} \mathrm{C}>31^{\circ} \mathrm{C}>33^{\circ} \mathrm{C}$ \\
\hline Location & 1.114 & 2 & & 0.557 & 39.654 & $<0.001$ & LI, HPR $>$ BBR \\
\hline Temp $\times$ Location & 0.257 & 6 & & $4.283 \times 10^{-2}$ & 3.048 & $<0.001$ & \\
\hline \multicolumn{8}{|c|}{ b) ANOVA for repeated measures } \\
\hline \multicolumn{8}{|c|}{ Within subjects } \\
\hline Day & 0.538 & 7 & 5.312 & 0.101 & 33.596 & $<0.001$ & $\mathrm{~d} 15<\mathrm{d} 17<\mathrm{d} 19<\mathrm{d} 25<\mathrm{d} 27$ \\
\hline Day $\times$ Location & 0.115 & 14 & 10.625 & $1.084 \times 10^{-2}$ & 3.596 & $<0.001$ & \\
\hline Day $\times$ Temp & 0.779 & 21 & 15.937 & $4.889 \times 10^{-2}$ & 16.225 & $<0.001$ & \\
\hline Day $\times$ Temp $\times$ Location & 0.245 & 42 & 31.874 & $7.682 \times 10^{-3}$ & 2.549 & $<0.001$ & \\
\hline \multicolumn{8}{|l|}{ Between subjects } \\
\hline Temp & 148.110 & 3 & & 49.370 & 5009.194 & $<0.001$ & $26^{\circ} \mathrm{C}>29^{\circ} \mathrm{C}>31^{\circ} \mathrm{C}$ \\
\hline Location & 1.850 & 2 & & 0.925 & 93.865 & $<0.001$ & $\mathrm{LI}>\mathrm{HPR}>\mathrm{BBR}$ \\
\hline Temp $\times$ Location & 1.085 & 6 & & 0.181 & 18.353 & $<0.001$ & \\
\hline
\end{tabular}

The 6 northernmost populations of Turbinaria reniformis (Lizard Island, Ribbon Reef \# 5, Pickersgill Reef, Elford Reef, Flora Reef, Noreaster Reef) were dominated by clade D (GenBank Accession \# AY327073) zooxanthellae, with Symbiodinium C1 being present at low abundances in both upper and lower parts of all colonies. At Percy Island, all T. reniformis colonies harboured predominantly strain C1 except for one which harboured mainly clade D. At Heralds Prong Reef all colonies harboured mainly strain $\mathrm{C} 1$ but in 6 of the colonies low abundances of clade D were also detected. Symbiodinium C1 was the only detectable zooxanthella type in colonies from all other sites. The distribution of zooxanthellae did not correspond with shelf position (Table 1).

\section{DISCUSSION}

In this study, we have documented intra-specific differences in bleaching sensitivity of 2 coral species (Pocillopora damicornis and Turbinaria reniformis) from 3 geographically distinct locations along a latitudinal gradient of the GBR. The 2 coral taxa show distinct depth distributions (K. E. Ulstrup, R. Berkelmans, M. J. H. van Oppen pers. obs.) and are also likely to possess distinct host attributes not assessed in this study, which may influence their thermal tolerance. The results show that the temperature history (Fig. 2) and geographic distribution of zooxanthellae is of great importance to the bleaching sensitivity of corals and that even very bleaching resistant corals such as $T$. reniformis are photochemically sensitive to heat stress (Fig. 5B). Despite the fact that the coral genus Turbinaria has been shown to be one of the least susceptible taxa during natural bleaching events (Marshall \& Baird 2000), our experimental results show that the difference in susceptibility between T. reniformis and a sensitive species like $P$. damicornis is less than $2^{\circ} \mathrm{C}$ and may even be less than $1^{\circ} \mathrm{C}$ for a $2 \mathrm{wk}$ exposure. However, it should be noted that the rate of thermal ramping of $0.2^{\circ} \mathrm{C} / \mathrm{h}$ is faster than what corals are likely to experience in a natural setting, which may have influenced the measured difference in bleaching susceptibility between these 2 species.

We have shown genetic differences in the geographic distribution of the zooxanthella communities in Pocillopora damicornis and Turbinaria reniformis. The bleaching sensitivity of both $P$. damicornis and T. reniformis corresponded with the relative presence and dominance of clade D zooxanthellae. Although bleaching sensitivity in $P$. damicornis also corresponds to latitude, this does not appear to be the case for T. reniformis. This result reinforces the notion that 
temperature tolerance in some coral species may be driven by symbiont type and perhaps to a lesser extent by host biochemistry. Thus, this study provides support to functional differences existing among zooxanthella types whose traits are conferred upon the physiology of the coral host.

\section{Local adaptation and phenotypic plasticity}

Pocillopora damicornis has been affected by bleaching worldwide and has often served as an experimental species for studies of coral physiology in relation to bleaching (Glynn \& D'Croz 1990, D'Croz \& Maté 2004, Hill et al. 2004, Ralph et al. 2005). Glynn \& D'Croz (1990) found colonies of P. damicornis from an upwelling area in the Gulf of Panama to undergo greater bleaching at $30^{\circ} \mathrm{C}$ in controlled experiments than the same species from the non-upwelling Gulf of Chiriqui, where ambient temperatures were higher and more stable. Our data confirm that P. damicornis colonies are highly sensitive to elevated temperatures and that adaptation to local temperatures (Fig. 2) influences their bleaching resistance, as latitudinal differences in bleaching sensitivity were maintained after laboratory acclimation. Thus, corals pre-exposed to high temperature (i.e. low latitude: Lizard Island) were less sensitive to the experimental temperature treatments and corals accustomed to relatively lower temperature (i.e. high latitude: Wistari Reef) bleached earlier and more severely (Fig. 5A). Lizard Island and Ribbon \# 5 in the northern section of the GBR and Big Broadhurst Reef in the central section of the GBR showed low abundance of clade D in some explants (Table 1) suggesting potential capacity for symbiont shuffling (i.e. changes in the relative abundance of different zooxanthella types present inside the host tissues (Baker 2003)) in response to elevated temperatures. The pattern however is not consistent throughout the northern section of the GBR suggesting that factors other than temperature are driving symbiont selection.

The populations of Turbinaria reniformis showed less sensitivity to elevated temperature than Pocillopora damicornis (Fig. 5). Temperature resistance in T. reniformis corresponded with the presence of clade D symbionts (Table 1). The most bleaching resistant population (Lizard Island) showed dominance of clade D symbionts, followed by explants from Heralds Prong Reef which harboured clade D symbionts at a lower abundance than strain C1 and explants from Big Broadhurst Reef which did not show any presence of clade D symbionts (Table 1). This suggests that clade D symbionts are selected for in populations exposed to high temperatures, such as found in the northern GBR.
Baker et al. (2004) found that the abundance of clade D symbionts was high at locations where recent bleaching had occurred. Also, van Oppen et al. (2005) found that several Acropora millepora populations in the southern section of the GBR, which had bleached in 2002, showed an increased abundance of clade D since this bleaching event. The co-occurrence of genetically distinct symbionts in $T$. reniformis among reefs on the southern GBR (Heralds Prong Reef and Percy Island, Table 1) might thus be due to past bleaching events on these reefs.

\section{Mortality}

Both species showed $100 \%$ mortality when exposed to $33^{\circ} \mathrm{C}$ (Pocillopora damicornis after 5 to $7 \mathrm{~d}$ depending on location and Turbinaria reniformis after $13 \mathrm{~d}$ ) (Fig. 3). Persistent exposure to $33^{\circ} \mathrm{C}$ was beyond the bleaching resistance capacity of both corals in our experiment. However, corals may show greater resistance during natural thermal events, during which thermal maxima are achieved more slowly, providing greater time for acclimatization of the holobiont. The corals were collected in the austral winter. It is possible that corals show greater resistance to heat stress if they are experimentally tested in summer when acclimated to higher temperature (Brown et al. 2002). Indeed, Berkelmans \& Willis (1999) found that the winter bleaching threshold of $P$. damicornis on the GBR was $1^{\circ} \mathrm{C}$ lower than the summer threshold for this species and proposed that the winter temperature bleaching threshold of 31 to $32^{\circ} \mathrm{C}$ was a reliable predictor of subsequent mortality.

\section{Zooxanthella density}

Significant declines in zooxanthella densities were not observed after exposure to $29^{\circ} \mathrm{C}$ in either species from any of the populations examined (Fig. 4). However, the variation in zooxanthella density was generally greater in Pocillopora damicornis explants (Fig. 4A) than in Turbinaria reniformis explants (Fig. 4B). This suggests that the number of replicates examined was insufficient to detect differences which might have been present between control and experimental explants.

Corals have been found to exhibit increased host respiration in relation to photosynthesis at lower sea temperatures (Coles \& Jokiel 1977). In order to compensate for loss of photosynthates, corals may increase the number of zooxanthellae inside their tissues. Prior to experimental treatment the highest zooxanthella densities in Pocillopora damicornis were found at Wistari 
Reef (Table 2). Wistari Reef explants also showed the largest relative decrease in zooxanthella density as observed after exposure to $31^{\circ} \mathrm{C}$ (Fig. 4A), possibly due to their thermal history of lower temperatures (Fig. 2) than explants from Big Broadhurst Reef and Lizard Island.

All populations of Turbinaria reniformis were sensitive to exposure to $31^{\circ} \mathrm{C}$ but only explants from Lizard Island returned to pre-bleaching levels of zooxanthella density during recovery (Fig. 4B). This possibly reflects the degree of damage incurred during the period of exposure to elevated temperatures, which was not as severe in explants from Lizard Island as in explants from Big Broadhurst Reef and Heralds Prong Reef as indicated by measurements of photochemical efficiency $\left(F_{\mathrm{v}} / F_{\mathrm{m} ;}\right.$ Fig. 5B).

\section{Photochemical efficiency}

Decreased photochemical efficiency $\left(F_{\mathrm{v}} / F_{\mathrm{m}}\right)$ is an indication of PSII inactivation and has typically been found to follow the onset of bleaching (Hoegh-Guldberg \& Smith 1989). Both species of coral showed a decline in $F_{\mathrm{v}} / F_{\mathrm{m}}$ over $14 \mathrm{~d}$ of elevated temperature at 31 and $33^{\circ} \mathrm{C}$ relative to that observed at the control temperature (Fig. 5). However, the variance in photochemical decline was greater for Pocillopora damicornis (Fig. 5A) than for Turbinaria reniformis (Fig. 5B) indicating less intra-specific stability of the holobiont. During the recovery period after exposure to $31^{\circ} \mathrm{C}$, the $F_{\mathrm{v}} / F_{\mathrm{m}}$ response of $P$. damicornis colonies from Big Broadhurst Reef and Wistari Reef continued to decline (Fig. 5A[c]), whereas T. reniformis colonies showed signs of recovery after $3 \mathrm{~d}$ and were able to revert the photoinactivation observed during the period of elevated temperature exposure (Fig. 5B[c]). The duration of bleaching may cause a bleaching sensitive species such as $P$. damicornis to lose its ability to recover due to irreparable damage to the PSII (Hill et al. 2004). However, a prolonged recovery period could result in an increase in the $F_{\mathrm{v}} / F_{\mathrm{m}}$ signal as the photosynthetic apparatus is repaired (Warner et al. 1999).

\section{Symbiont selection}

Pocillopora damicornis explants were all dominated by Symbiodinium type C1. The presence of similar Symbiodinium communities in geographically distinct populations of $P$. damicornis suggests that this coralalgal association is physiologically compatible with near average summer temperature conditions. This specificity may be advantageous during normal conditions but may also be sub-optimal during extreme tem- peratures caused by climate change. Limited gene flow from $P$. damicornis populations adapted to different temperature regimes (Ayre \& Hughes 2000) may drive populations to relatively higher temperature tolerance through local adaptation. None of the $P$. damicornis populations exhibited dominance of the more heat tolerant Symbiodinium clade D. However, a small number of $P$. damicornis colonies at 3 out of 6 northern sites and Big Broadhurst Reef in the central section of the GBR exhibited low abundances of clade D in relation to strain C1 (Table 1). Thus, the presence of clade $\mathrm{D}$ does not correspond well with latitude, which suggests that $P$. damicornis on the GBR exhibits limited plasticity in its selection for symbionts.

The distribution of genetically distinct symbionts in experimental populations of Turbinaria reniformis corresponds with $F_{\mathrm{v}} / F_{\mathrm{m}}$ measurements, suggesting that clade D symbionts are physiologically more robust than C1 symbionts during exposure to elevated temperatures (Table 1, Fig. 5). Given that clade D symbionts have been found to be thermo-tolerant (Glynn et al. 2001, Baker et al. 2004, Fabricius et al. 2004, Rowan 2004), reef regions containing this group of symbionts may form source populations for the colonisation of disturbed reefs. Only very low levels of gene flow have been found to be necessary to permit the spread of advantageous genotypes (Morjan \& Rieseberg 2004). The spread of clade D symbionts could thus provide a means to withstand severe future reef degradation due to bleaching in corals which exhibit flexibility in their symbiont preference, although an ecological cost may be associated with shuffling to a different type of zooxanthella (Little et al. 2004).

\section{CONCLUSIONS}

We found that the bleaching sensitivity and recovery of Pocillopora damicornis corresponded with latitude i.e. high-latitude corals bleached prior to and at lower temperatures than low-latitude corals. The 2 coral taxa showed different affinities for distinct zooxanthella genotypes. Although the northern and central experimental populations of $P$. damicornis harboured low abundances of clade D in some explants, we believe that the observed latitudinal difference in bleaching sensitivity suggests that the role of symbiont shuffling is inferior to that of local adaptation in this species. In contrast, the bleaching response of Turbinaria reniformis did not correspond with latitude but with the presence of thermo-tolerant clade D symbionts. Thus, corals which did not harbour detectable levels of Symbiodinium clade D were most sensitive to temperature elevation, irrespective of local temperature regimes. 
Acknowledgements. We thank Dr. B. Kelaher (University of Technology, Sydney) for statistical advice. We also acknowledge the support provided by the Department of Environmental Science, UTS, and thank 3 anonymous reviewers for their valuable comments. Neal Cantin kindly provided Pocillopora damicornis samples from Magnetic Island. The research was funded by AIMS and the National Geographic Society. Coral collections were made under the GBRMPA permit number G03/9322.1. This is contribution number 205 from the Institute of Water and Resource Management (IWERM).

\section{LITERATURE CITED}

Ayre DJ, Hughes TP (2000) Genotypic diversity and gene flow in brooding and spawning corals along the Great Barrier Reef, Australia. Evolution 54:1590-1605

Baker AC (2001) Ecosystems - reef corals bleach to survive change. Nature 411:765-766

Baker AC (2003) Flexibility and specifity in coral-algal symbiosis: diversity, ecology, and biogeography of Symbiodinium. Annu Rev Ecol Evol Syst 34:661-89

Baker AC, Starger C J, McClanahan TR, Glynn PW (2004) Corals' adaptive response to climate. Nature 430:741

Berkelmans R (2002) Time-integrated thermal bleaching thresholds of reefs and their variation on the Great Barrier Reef. Mar Ecol Prog Ser 229:73-82

Berkelmans R, Oliver JK (1999) Large-scale bleaching of corals on the Great Barrier Reef. Coral Reefs 18:55-60

Berkelmans R, Willis B (1999) Seasonal and local spatial patterns in the upper thermal limits of corals on the inshore Central Great Barrier Reef. Coral Reefs 18:55-60

Berkelmans R, De'ath G, Kininmonth S, Skirving WJ (2004) A comparison of the 1998 and 2002 coral bleaching events on the Great Barrier Reef: Spatial correlation, patterns and predictions. Coral Reefs 23:74-83

Brown BE, Downs CA, Dunne RP, Gibb SW (2002) Exploring the basis of thermotolerance in the reef coral Goniastrea aspera. Mar Ecol Prog Ser 242:119-129

Coles SL, Jokiel PL (1977) Effects of temperature on photosynthesis and respiration in hermatypic corals. Mar Biol 43:209-216

Coles SL, Jokiel PL, Lewis CR (1976) Thermal tolerance in tropical versus subtropical Pacific reef corals. Pac Sci 30(2):159-166

D'Croz LD, Maté JL (2004) Experimental responses to elevated water temperature in genotypes of the reef coral Pocillopora damicornis from upwelling and non-upwelling environments in Panama. Coral Reefs 23 (4):473-483

Fabricius KE, Mieog JC, Colin PL, Idip D, van Oppen MJH (2004) Identity and diversity of coral endosymbionts (zooxanthellae) from 3 Palauan reefs with contrasting bleaching, temperature and shading histories. Mol Ecol 13: 2445-2458

Glynn PW, D'Croz LD (1990) Experimental evidence for high temperature stress as the cause of El Niño-coincident coral mortality. Coral Reefs 8:181-191

Glynn PW (1996) Coral reef bleaching: fact, hypothesis and implications. Global Change Biology 2(6):495-509

Glynn PW, Mate JL, Baker AC (2001) Coral bleaching and mortality in Panama and Equador during the 1997-1998 El Nino-Southern Oscillation event: Spatial/temporal patterns and comparisons with the 1982-1983 event. Bull Mar Sci 69(1):79-109

Hill R, Larkum AWD, Frankart C, Kühl M, Ralph PJ (2004) Loss of functional Photosystem II reaction centres in zooxanthellae of coral exposed to bleaching conditions: using fluorescence rise kinetics. Photosynth Res 82:59-72

Hoegh-Guldberg O (1999) Climate change, coral bleaching and the future of the world's coral reefs. Mar Freshw Res 50:839-866

Hoegh-Guldberg O, Salvat B (1995) Periodic mass bleaching of reef corals along the outer reef slope in Moorea, French Polynesia. Mar Ecol Prog Ser 121:181-190

Hoegh-Guldberg O, Smith GJ (1989) The effect of sudden changes in temperature, light and salinity on the population density and export of zooxanthellae from the reef corals Stylophora pistillata (Esper) and Seriatopora hystrix (Dana). J Exp Mar Biol Ecol 129:279-303

IPCC (Intergovernmental Panel on Climate Change) (2001) Technical Summary of the Working Group I report. IPCC, Third Assessment Report, Cambridge

Jones RJ, Hoegh-Guldberg O, Larkum AWD, Schreiber U (1998) Temperature-induced bleaching of corals begins with impairment of the $\mathrm{CO}_{2}$ fixation mechanism in zooxanthellae. Plant Cell Environ 21:1219-1230

Little AF, van Oppen MJH, Willis BL (2004) Flexibility in algal endosymbioses shapes growth in reef corals. Science 304 : 1492-1494

Loh WKW, Loi T, Carter D, Hoegh-Guldberg O (2001) Genetic variability of the symbiotic dinoflagellates from the wide ranging coral species Seriatopora hystrix and Acropora longicyathus in the Indo-West Pacific. Mar Ecol Prog Ser 222:97-107

Loya Y, Sakai K, Yamazoto K (2001) The winner and the losers. Ecol Let 4:122-131

Marshall PA, Baird AH (2000) Bleaching of corals on the Great Barrier Reef: differential susceptibilities among taxa. Coral Reefs 19:155-163

Morjan CL, Rieseberg LH (2004) How species evolve collectively: implications of gene flow and selection for the spread of advantageous alleles. Mol Ecol 13:1341-1356

Muscatine L (1990) The role of symbiotic algae in carbon and energy flux in reef corals. In: Dubinsky Z (ed) Ecosystems of the world: coral reefs. Elsevier, Amsterdam, p 75-87

Quinn GP, Keough MJ (2002) Experimental design and data analysis for biologists. Cambridge University Press, Cambridge, Chapter 10

Ralph PJ, Gademann R, Larkum AWD (2001) Zooxanthellae expelled from bleached corals at $33^{\circ} \mathrm{C}$ are photosynthetically competent. Mar Ecol Prog Ser 220:163-168

Ralph PJ, Schreiber U, Gademann R, Kuhl M, Larkum AWD (2005) Coral photobiology studied with a new imaging pulse amplitude modulated fluorometer. J Phycol 41(2): 335-342

Rodriguez-Lanetty M, Loh W, Carter D, Hoegh-Guldberg O (2001) Latitudinal variability in symbiont specificity within the widespread scleractinian coral Plesiastrea versipora. Mar Bio 138:1175-1181

Rowan R (2004) Thermal adaptation in reef coral symbionts Nature 430:742

Rowan R, Knowlton N, Baker A, Jara J (1997) Landscape ecology of algal symbionts creates variation in episodes of coral bleaching. Nature 388:265-269

Savage AM, Trapido-Rosenthal H, Douglas AE (2002) On the functional significance of molecular variation in Symbiodinium, the symbiotic algae of Cnidaria: photosynthetic response to irradiance. Mar Eco Prog Ser 244:27-37

Schreiber U (2004) Pulse-amplitude-modulation (PAM) fluorometry and saturation pulse method: an overview. In: Papageorgiou GC, Govindjee (eds) Chlorophyll fluorescence: a signature of photosynthesis. Kluwer Academic Publishers, Dordrecht, p 279-319 
Stimson J (1997) The annual cycle of density of zooxanthellae in the tissues of field and laboratory-held Pocillopora damicornis (Linnaeus). J Exp Mar Biol Ecol 214:35-48

Sunnucks P, Wilson ACC, Beheregaray LB, Zenger K, French J, Taylor AC (2000) SSCP is not so difficult: the application and utility of single-stranded conformation polymorphism in evolutionary biology and molecular ecology. Mol Ecol 9: 1699-1710

Toller WW, Rowan R, Knowlton N (2001) Zooxanthellae of the Montastraea annularis species complex: patterns of distribution of four taxa of Symbiodinium on different reefs and across depths. Biol Bull 201:348-359

Turner P, Berkelmans R, Brodie M (2002) Precise set-point control of temperature for coral bleaching experiments. Mar Tech Soc J 36:70-75

Ulstrup KE, van Oppen, MJH (2003) Geographic and habitat partitioning of genetically distinct zooxanthellae (Symbio-

Editorial responsibility: Otto Kinne (Editor-in-Chief),

Oldendorf/Luhe, Germany dinium) in Acropora corals on the Great Barrier Reef. Mol Ecol 23:3477-3484

van Oppen M, Palstra FP, Piquet AMT, Miller DJ (2001) Patterns of coral-dinoflagellate associations in Acropora: significance of local availability and physiology of Symbiodinium strains and host-symbiont selectivity. Proc R Soc London B 268:1759-1767

van Oppen MJH, Mahiny AJ, Done TJ (2005) Geographic distribution of zooxanthella types in three coral species on the Great Barrier Reef sampled after the 2002 bleaching event. Coral Reefs 24(3):482-487

Warner ME, Fitt WK, Schmidt GW (1999) Damage to photosystem II in symbiotic dinoflagellates: A determinant of coral bleaching. Proc Nat Acad Sci USA 96:8007-8012

West JM, Salm RV (2003) Resistance and resilience to coral bleaching: Implication for coral reef conservation and management. Conserv Biol 17(4):956-967

Submitted: July 20, 2005; Accepted: December 19, 2005

Proofs received from author(s): March 27, 2006 